\title{
Edukasi Kesehatan tentang Pencegahan Gout Arthritis di Desa Bangga Kabupaten Sigi
}

\author{
${ }^{1}$ Nur Febrianti, ${ }^{2}$ Yulta Kadang, ${ }^{3}$ Iman Hikam \\ 1,2,3Akademi Keperawatan Justitia \\ Korespondensi: nur.febrianti90@yahoo.co.id
}

\begin{abstract}
Tri dharma of higher education is the obligation of lecturers, and one of them is community service. This service raised the theme of health education on the prevention of gout arthritis. Previously, a Health screening was carried out with the Sheep Indonesia Foundation that the problem found in Proud Village was gout arthritis. Proud Village is a remote area in Sigi Regency. The purpose of this community service is to increase public knowledge about the prevention of gouty arthritis. The method of implementing community service with direct counseling techniques to the community with media flip chart and leaflet. The results of the service, the community is very enthusiastic to listen to the material. Previously, many residents did not know about gout arthritis. This is reflected in the many questions asked regarding the disease. In the evaluation session, the community was given questions and on average the community could answer correctly according to the material provided. The conclusion of community service activities has been carried out smoothly. The community response is very good and it is hoped that the community can prevent the occurrence of gout arthritis, and this community service activity can be carried out regularly.
\end{abstract}

Keywords: health education, prevention, Gout Arthritis, community service.

\begin{abstract}
Abstrak: Tri dharma perguruan Tinggi merupakan kewajiban dosen, dan salah satunya adalah pengabdian kepada masyarakat. Pengabdian ini mengangkat tema health education tentang pencegahan gout arthritis. Sebelumnya dilakukan screening Kesehatan bersama Yayasan Sheep Indonesia bahwa permasalahan yang didapatkan di Desa Bangga adalah gout artritis. Desa Bangga merupakan daerah terpencil yang ada di Kabupaten Sigi. Tujuan pengabdian kepada masyarakat ini untuk meningkatkan pengetahuan masyarakat tentang pencegahan gout Arthritis. Metode pelaksanaan pengabdian kepada masyarakat dengan tehnik penyuluhan langsung kepada masyarakat dengan media Flip chart dan Leaflet. Hasil pengabdian, masyarakat sangat antusias untuk mendengarkan materi. Sebelumnya banyak warga yang kurang mengetahui penyakit gout artritis. Hal ini tercermin banyaknya pertanyaan yang diajukan terkait penyakit tersebut. Pada sesi evaluasi, masyarakat diberikan pertanyaan dan rata-rata masyarakat bisa menjawab dengan benar sesuai dengan materi yang diberikan. Kesimpulan kegiatan pengabdian masyarakat telah terlaksana dengan lancar. Sambutan masyarakat yang sangat baik dan diharapkan agar masyarakat dapat mencegah terjadinya gout arthritis, serta kegiatan pengabdian masyarakat ini dapat dilakukan secara rutin.
\end{abstract}

Kata kunci:health education, pencegahan,Gout Arthritis, pengabdian kepada masyarakat.

\section{PENDAHULUAN}

Gout merupakan gangguan metabolik yang ditandai dengan artritis inflamasi akut yang dipicu oleh kristalisasi urat dalam sendi ${ }^{1}$. Gout merupakan kelainan tulang metabolik dimana metabolism purin (protein) diubah dan produk penggantinya, asam urat terakumulasi². Gout terjadi sebagai respon terhadap produksi berlebihan atau ekskresi asam urat yang kurang, menyebabkan tingginya kadar asam uratdalam darah (hiperurisemia) dan pada cairan tubuh lainnya, termasuk cairan synovial ${ }^{1}$. Artritis gout lebih banyak terjadi pada pria dari pada wanita. Pada pria sering terjadi di usia pertengahan, sedangkan pada wanita biasanya mendekati masa menopause ${ }^{3}$.

Berdasarkan data dari Riskesdas bahwa Prevalensi penyakit sendi di Indonesia sebesar 7,30\%, dimana prevalensi yang paling tinggi di provinsi Aceh sebesar 13,26\%, selanjutnya Bengkulu sebesar $12,11 \%$, bali sebesar $10,46 \%$, Papua $10,43 \%$, dan urutan yang cukup jauh yaitu provinsi Sulawesi tengah sebesar $7,72 \%$. Selanjutnya di provinsi Sulawesi tengah terdapat beberapa daerah yang prevalensi penyakit sendi cukup tinggi, antara lain morowali sebesar 13,92\%, donggala sebesar $13,54 \%$, dan sigi sebesar $12,10 \%{ }^{4}$.

Berdasarkan data dari provinsi Sulawesi tengah menunjukkan bahwa Usia diatas 15 tahun banyak yang terkena penyakit sendi, diantaranya usia 65-74 tahun sebesar 21,82\%, Usia >75 tahun sebesar $19,64 \%$, usia 55-64 tahun sebesar 18,61\%, dan usia 45-54 sebesar 11,78\%5. Sejalan dengan penelitian Rahmah et.al di RS Anutapura palu menunjukkan bahwa penyakit gout arthritis sebagian besar berjenis kelamin laki- laki 71,86\%, berumur $18-59$ tahun $71,86 \%$, dan pendidikan SMA $21,86 \%{ }^{6}$.

This is an open-access article under the CC BY 4.0 International License

(c) Idea PengabdianMasyarakat (2022)

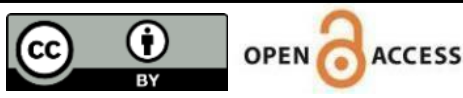


Setelah melakukan screening Kesehatan dengan Yayasan Sheep Indonesia bahwa permasalahan yang didapatkan di Desa Bangga adalah gout arthritis. Desa Bangga merupakan daerah terpencil yang ada di Kabupaten Sigi, Sulawesi Tengah, serta masyarakat di Desa Bangga jauh di sentuh Pendidikan. Masyarakat tersebut sangat membutuhkan edukasi tentang gout arthritis yang dimana diharapkan dapat meningkatkan pengetahuan tentang gout arthritis, sehingga dapat mencegah terjadinya gout arthritis pada masyarakat di Desa Bangga, kabupaten Sigi, Sulawesi Tengah.

\section{METODE PELAKSANAAN}

Penyuluhan Kesehatan ini dibagi dalam 4 tahapan diantaranya adalah:

Tahap 1. Pengumpulan data kesehatan

Pengumpulan data telah dilakukan bersama Yayasan Sheep Indonesia di desa Bangga, Kabupaten Sigi pada tanggal 11 Oktober 2021.

Tahap 2. Health edukasi

Tahap health education dilakukan oleh tim pada tanggal 21 oktober 2021 menggunakan media Flip chart dan Leaflet, materi health education yang diberikan kepada masyarakat berdasarkan Buku saku kader pengontrolan asam urat di masyarakat diantaranya adalah:

1. Pengertian gout arthritis

2. Penyebab gout arthritis

3. Tanda dan Gejala gout arthritis

4. Kadar Normal gout arthritis dalam tubuh

5. Pengobatan gout arthritis

6. Pencegahan gout arthritis

7. Beberapa hal yang perlu diperhatikan terkait gout arthritis ${ }^{7}$

Tahap 3. Evaluasi

Evaluasi tingkat pengetahuan dilakukan pada hari yang sama, hal tersebut bertujuan untuk mengetahui pemahaman masyarakat setelah diberikan health education tentang pencegahan gout arthritis.

Tahap 4. Pembagian Leaflet

Pembagian leaflet dilakukan pada saat selesai evaluasi, bertujuan agar masyarakat dapat membaca materi tentang pecegahan gout arthritis pada waktu senggang di rumah masing-masing.

\section{HASIL DAN PEMBAHASAN}

Pengumpulan data dilakukan sebelumnya bersama Yayasan Sheep Indonesia di desa Bangga Kabupaten Sigi pada tanggal 11 Oktober 2021. Setelah data gout arthritis ditemukan, maka direncanakan Kegiatan pengabdian kepada masyarakat. Kegiatan ini dilaksanakan pada hari Kamis, 21 Oktober 2021 pada pukul 09.00-11.00 wita. Satu hari sebelum kegiatan ini dilakukan, Yayasan sheep Indonesia membantu kami untuk kontrak waktu sebelumnya dengan masyarakat setempat perihal kegiatan penyuluhan kesehatan yang akan dilakukan, sehingga masyarakat dapat meluangkan waktunya untuk hadir mengikuti penyuluhan Kesehatan. Masyarakat saangat antusiat dengan kegiatan ini, masyarakat telah berkumpul di tempat yang telah

This is an open-access article under the CC BY 4.0 International License

(c) Idea PengabdianMasyarakat (2022)

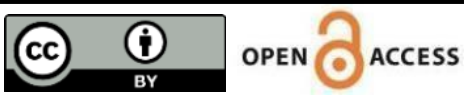


disepakati sebelum pukul 09.00, sehingga kegiatan dimulai sesuai dengan waktu yang direncanakan. Pada saat kegiatan tersebut dimulai, masyarakat sangat antusias untuk mendengarkan materi-materi yang kami sampaikan (materi terlampir). Pada sesi penyampaian materi, ternyata banyak warga yang belum cukup tau atau paham dengan penyakit seperti gout artritis. Hal ini tercermin banyaknya pertanyaan yang diajukan terkait penyakit tersebut. Dari 20 warga yang hadir ditemukan 5 warga yang pernah memiliki tanda dan gejala gout artritis. Pada sesi evaluasi, masyarakat diberikan pertanyaan dan rata-rata masyarakat bisa menjawab dengan benar sesuai dengan materi yang diberikan. Kegiatan pengabdian masyarakat ini sangat bermanfaat melihat dengan permasalahan yang dialami oleh masyarakat di daerah tersebut. Sehingga masyarakat dapat mencegah terjadinya gout artritis dan memeriksakan dirinya dan keluarga ke tempat pelayanan Kesehatan terdekat.

Kegiatan ini bertujuan meningkatkan pengetahuan masyarakat tentang pencegahan gout arthritis. Berdasarkan penelitian yang telah dilakukan Minggawati et al menunjukkan bahwa pengetahuan penderita gout arthritis tentang penyakit gout arthritis dengan kategori pengetahuan cukup sebesar $84,2 \%{ }^{8}$. Hal ini didukung dengan penelitian Runtuwene et al yang menunjukkan bahwa tingkat pengetahuan kurang mengalami peningkatan kadar asam urat 4,262 lebih banyak dari subjek yang memiliki pengetahuan baik dan cukup. Serta menyarankan bagi masyarakat, perlu menjaga pola makan terutama makanan sumber purin yang dapat meningkatkan kadar asam urat dalam darah ${ }^{9}$. Dari hasil penelitian Ferdiani et al Diperoleh nilai $p$-value 0,000 dengan nilai koefisien korelasi sebesar 0,706 (tingkat kuat), korelasi antara penyuluhan kesehatan dengan tingkat pengetahuan adalah positif, artinya semakin baik pengetahuan semakin baik pula mengerti diet gout arthtritis ${ }^{10}$. Menurut Minggawati et al bahwa perlu melakukan penyuluhan minimal sebulan sekali sehingga penderita dapat mencegah atau mengurangi resiko terjadinya penyakit gout arthritis 8 . Dengan demikian Health education yang telah dilakukan sangat bermanfaat bagi masyarakat sekitar, serta diharapkan dapat meminimalisir angka kejadian gout arthritis khususnya di Desa Bangga, Kabupaten Sigi.

Tabel 1

\begin{tabular}{lc}
\hline \multicolumn{1}{c}{ Indikator Kegiatan } & Keterangan \\
\hline $\begin{array}{l}\text { Peningkatkan pengetahuan masyarakat tentang pencegahan gout } \\
\text { arthritis }\end{array}$ & Terlaksana \\
\hline Peningkatan Kesehatan masyarakat & Terlaksana \\
\hline
\end{tabular}
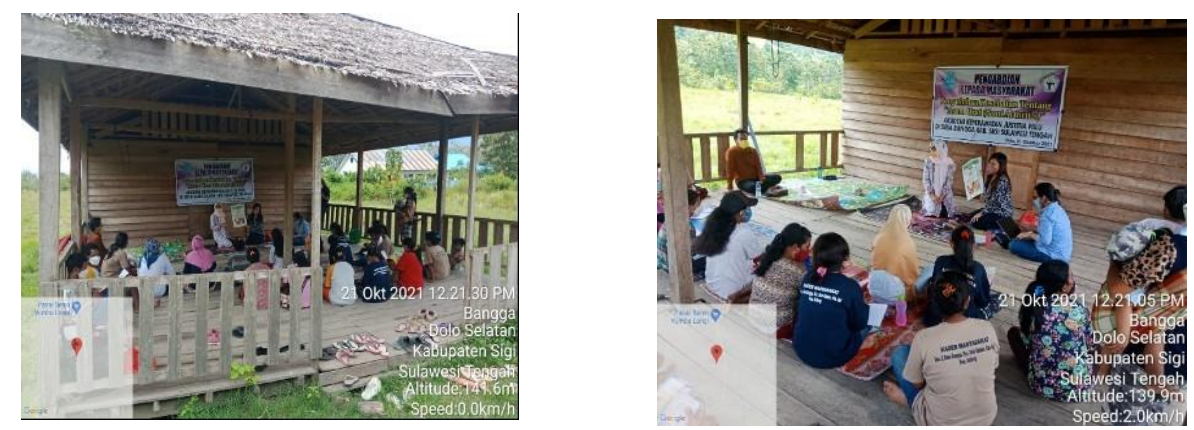

Gambar 1 dan 2. Kegiatan Pengabdian Masyarakat

This is an open-access article under the CC BY 4.0 International License

(C) Idea PengabdianMasyarakat (2022)

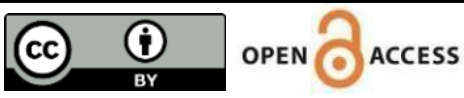




\section{KESIMPULAN}

Kegiatan pengabdian masyarakat telah terlaksana dengan lancar. Sambutan masyarakat yang sangat baik dan diharapkan agar masyarakat dapat mencegah terjadinya gout arthritis, kegiatan pengabdian masyarakat ini dapat dilakukan secara rutin, serta pengabdian kepada masyarakat ini merupakan salah satu kewajiban dosen dalam melaksanakan Tri Dharma Perguruan Tinggi.

\section{UCAPAN TERIMA KASIH}

Kami tim pengabdian kepada masyarakat Akademi Keperawatan Justitia Palu mengucapkan terima kasih kepada Pemerintah kabupaten Sigi yang telah memberikan kesempatan kepada kami untuk melaksanakan pengabdian kepada masyarakat di desa Bangga, Yayasan Sheep Indonesia yang banyak membantu dan memberikan informasi terkait masalah Kesehatan di desa Bangga, Tim dosen yang telah menyusun dan membuat laporan, serta Direktur dan UPPM Akademi Keperawatan Justitia Palu yang telah memberikan motivasi untuk melakukan pengabdian kepada masyarakat.

\section{DAFTAR PUSTAKA}

1. LeMone P, Burke KM, Bauldoff G. Buku ajar keperawatan medikal bedah vol. 4. 5th ed. Jakarta: EGC; 2019.

2. Black JM, Hawks JH. Keperawatan Medikal Bedah. 8th ed. Singapura: Elsevier; 2014.

3. Mansjoer A, Triyanti K, Savitri R, Wardhani wahyu ika, Setiowulan W. Kapita selekta kedokteran jilid 1. 3rd ed. Jakarta: Media Aesculapius; 2009.

4. Riskesdas. Laporan Nasional RISKESDAS 2018 : Badan Penelitian dan Pengembangan Kesehatan [Internet]. Badan Penelitian dan Pengembangan Kesehatan. Jakarta: BALITBANGKES; 2018. Available from:

http://labdata.litbang.kemkes.go.id/images/download/laporan/RKD/2018/Laporan_Nasional_RKD2018 _FINAL.pdf

5. Riskesdas. Laporan Provinsi sulawesi tengah Riskesdas 2018. Badan Penelitian dan Pengembangan Kesehatan. Jakarta; 2018.

6. Rahmah NF, Mukaddas A, Safarudin. Profil Penggunaan Obat Pada Pasien Gout Dan Hiperurisemia Di Rsu Anutapura Palu. Galen J Pharm. 2016;2(2):118-23.

7. Madyaningrum E, Kusumaningrum F, Wardani RK, Susilaningrum AR, Ramadhani A. Buku Saku Kader Pengontrolan Asam Urat Di Masyarakat. Yogyakarta: HDSS Sleman bekerja sama dengan Tim Pengabdian Masyarakat Fakultas Kedokteran, Kesehatan Masyarakat dan Keperawatan, Universitas Gadjah Mada; 2020. 38 p.

8. Minggawati ZA, Fauziah SN, Rusmita E. Pengetahuan Penderita Gout Arthritis Tentang Penyakit Gout Arthritis Di Puskesmas Pasirlayung Kota Bandung. J Kesehat Aeromedika [Internet]. 2019;V(1). Available from: https://jurnal.poltekestniau.ac.id/jka/article/view/23

9. Runtuwene Y, Purba RB, Kereh PS. Asupan Purin dan Tingkat Pengetahuan dengan Kadar Asam Urat di Puskesmas Rurukan Kota Tomohon. GIZIDO. 2016;8(2).

10. Ferdiani FDN, Yuliana N, Estiningtyas. Pengaruh Penyuluhan Kesehatan Diet Gout Artritis terhadap Tingkat Pengetahuan Lansia di Desa Karangmojo. Stethoscope. 2021;2(1):32-8. 